\title{
Electrophysiological Properties of Medium Spiny Neuron Subtypes in the Caudate-Putamen of Prepubertal Male and Female Drd1a-tdTomato Line 6 BAC Transgenic Mice
}

\author{
Jaime A. Willett, ${ }^{1,2,3}$ Jinyan Cao, ${ }^{1,2}$ David M. Dorris, ${ }^{1}{ }^{\circledR}$ Ashlyn G. Johnson, ${ }^{4}$ Laura A. Ginnari, ${ }^{1}$ and \\ John Meitzen ${ }^{1,2,5,6}$
}

https://doi.org/10.1523/ENEURO.0016-19.2019

${ }^{1}$ Department of Biological Sciences, ${ }^{2}$ W.M. Keck Center for Behavioral Biology, ${ }^{3}$ Graduate Program in Physiology, North Carolina State University, Raleigh, North Carolina 27695, ${ }^{4}$ Neuroscience Graduate Program, Emory University, Atlanta, Georgia 30322, ${ }^{5}$ Center for Human Health and the Environment, and ${ }^{6}$ Comparative Medicine Institute, North Carolina State University, Raleigh, North Carolina 27695

\begin{abstract}
The caudate-putamen is a striatal brain region essential for sensorimotor behaviors, habit learning, and other cognitive and premotor functions. The output and predominant neuron of the caudate-putamen is the medium spiny neuron (MSN). MSNs present discrete cellular subtypes that show differences in neurochemistry, dopamine receptor expression, efferent targets, gene expression, functional roles, and most importantly for this study, electrophysiological properties. MSN subtypes include the striatonigral and the striatopallidal groups. Most studies identify the striatopallidal MSN subtype as being more excitable than the striatonigral MSN subtype. However, there is some divergence between studies regarding the exact differences in electrophysiological properties. Furthermore, MSN subtype electrophysiological properties have not been reported disaggregated by biological sex. We addressed these questions using prepubertal male and female Drd1a-tdTomato line 6 BAC transgenic mice, an important transgenic line that has not yet received extensive electrophysiological analysis. We made acute caudate-putamen brain slices and assessed a robust battery of 16 relevant electrophysiological properties using whole-cell patch-clamp recording, including intrinsic membrane, action potential, and miniature EPSC (mEPSC) properties. We found that: (1) MSN subtypes exhibited multiple differential electrophysiological properties in both sexes, including rheobase, action potential threshold and width, input resistance in both the linear and rectified ranges, and mEPSC amplitude; (2) select electrophysiological properties showed interactions between MSN subtype and sex. These findings provide a comprehensive evaluation of mouse caudate-putamen MSN subtype electrophysiological properties across females and males, both confirming and extending previous studies.
\end{abstract}

Key words: caudate putamen; electrophysiology; intrinsic excitability; medium spiny neurons; rodent; sex differences

\section{Significance Statement}

The findings presented here provide a comprehensive evaluation of the electrophysiological properties of caudate-putamen medium spiny neuron (MSN) subtypes, both in terms of electrophysiological metrics and animal sex. These data selectively confirm, diverge from, and extend the findings of previous studies, providing a firm foundation on which to pursue future studies of caudate-putamen MSNs. 


\section{Introduction}

The most abundant neuron type in the mammalian caudate-putamen is the medium spiny neuron (MSN), also called the spiny projection neuron (Graveland and Difiglia, 1985; Gerfen and Surmeier, 2011). The MSN is the output neuron of the caudate-putamen and other striatal brain regions, and is implicated in a wide range of cognitive and sensorimotor behaviors and relevant striatal disorders (Kreitzer and Malenka, 2008; Koob and Volkow, 2010; Maia and Frank, 2011). To regulate these behaviors, MSNs integrate glutamatergic, dopaminergic, GABAergic, cholinergic, estrogenic, and other inputs to influence both internal and external targets. MSNs are phenotypically diverse, encompassing at least two different subtypes, which differ in neurochemistry, dopamine receptor expression, efferent targets, gene expression, functional roles, and electrophysiological properties (Gerfen et al., 1990; Cepeda et al., 2008; Gertler et al., 2008; Shuen et al., 2008; Ade et al., 2011; Kramer et al., 2011; Kreitzer and Berke, 2011; Chan et al., 2012; Kravitz et al., 2012; Ma et al., 2012, 2013; Planert et al., 2013; Fieblinger et al., 2014; Friend and Kravitz, 2014; Keeler et al., 2014; Gokce et al., 2016; Schier et al., 2017; Sebel et al., 2017; Ho et al., 2018).

These two MSN subtypes include the striatonigral and the striatopallidal. Striatonigral MSNs express D1 dopamine receptors, which are the product of the gene Drd1a, and contain the neuropeptides substance $P$ and dynorphin. Striatopallidal MSNs express D2 dopamine receptors, which are the product of the gene Drd2, and contain the neuropeptide enkephalin. Previous studies exploring caudate-putamen MSN subtype-specific electrophysiological properties have generally identified the Drd2expressing subtype as being more excitable compared with the Drd1a-expressing subtype. However, there is some divergence between studies regarding the exact differences in electrophysiological properties (Table 1), and few studies have comprehensively evaluated a wide variety of cellular electrophysiological properties in individual MSNs of identified subtypes. Furthermore, all previous studies of caudate-putamen MSN subtypes have been performed in rats or mice of either solely male or

Received January 14, 2019; accepted February 24, 2019; First published March 07, 2019.

The authors declare no competing financial interests.

J.A.W., J.C., and J.M. designed research; J.A.W. and J.C. performed research; J.A.W., D.M.D., A.G.J., L.A.G., and J.M. analyzed data; J.M. contributed unpublished reagents/analytic tools; J.A.W., D.M.D., and J.M. wrote the paper.

This work was supported by the Army Research Office STIR Award W911NF-15-1-0476, NIH R01MH109471 (J.M.), North Carolina State University Start-up Funds (J.M.), and P30ES025128 (Center for Human Health and the Environment). We thank Stephanie Proaño and Dr. Amanda Krentzel for their technical support, and Drs. Jonathan Ting, David Aylor, Heather Patisaul, and Scott Belcher for advice regarding mice selection and breeding.

Correspondence should be addressed to John Meitzen at Jemeitze@ ncsu.edu.

https://doi.org/10.1523/ENEURO.0016-19.2019

Copyright (C) 2019 Willett et al.

This is an open-access article distributed under the terms of the Creative Commons Attribution 4.0 International license, which permits unrestricted use, distribution and reproduction in any medium provided that the original work is properly attributed. unreported sex, typical of the majority of neuroscience preclinical studies (Beery and Zucker, 2011; Shansky and Woolley, 2016; Will et al., 2017). This is problematic given that striatal-mediated behaviors and disorders exhibit sex differences and/or sex steroid hormone sensitivity in phenotype and/or incidence (Calhoun, 1962; Eckel et al., 2000; Zurkovsky et al., 2007; Hosseini-Kamkar and Morton, 2014; Yoest et al., 2018), and that striatal region and developmental stage-influenced sex differences exist in MSN electrophysiological properties, at least in rats (Arnauld et al., 1981; Tansey et al., 1983; Mermelstein et al., 1996; Wissman et al., 2011; Dorris et al., 2015; Tozzi et al., 2015; Cao et al., 2016, 2018; Willett et al., 2016; Proaño et al., 2018).

To address these gaps in knowledge, we used female and male B6 Cg-Tg (Drd1a-tdTomato) line 6 Calak/J hemizygous mice, a bacterial artificial chromosome (BAC) transgenic mouse line initially developed in the laboratory of Dr. Nicole Calakos at Duke University (Ade et al., 2011). This mouse line and many others are widely used for experiments targeting neuronal subtypes (Valjent et al., 2009; Ting and Feng, 2014). An advantage of this particular BAC transgenic line is that it expresses a sensitive and specific fluorescent reporter for the Drd1a-expressing MSN subtype, enabling accurate identification of MSN subtypes within a single mouse. Other advantages of this mouse line compared with other candidates are that this line exhibits normal caudate-putamen-mediated behaviors and does not appear to show obvious cellular or physical confounds (Ade et al., 2011; Enoksson et al., 2012; Thibault et al., 2013). We made acute brain slices of male and female mouse caudate-putamen and then recorded individual MSN subtypes using whole-cell patchclamp. We analyzed a comprehensive battery of caudateputamen MSN subtype electrophysiological attributes to test the hypothesis that MSN electrophysiological properties differs by subtype across both males and females, including action potential, excitability, passive membrane and input resistance properties, and miniature EPSCs (mEPSCs).

\section{Materials}

\section{Animals}

Male B6 Cg-Tg (Drd1a-tdTomato) line 6 Calak/J mice and female C57BL/6 background mice were purchased from The Jackson Laboratory (JAX stock \#16204). During the first week after arrival mice were individually housed. After the first week mice were housed in male and female pairs to enable breeding of hemizygous offspring. Offspring aged postnatal day (P)17-P22 from F1 litters were used in experiments $(n=25)$ and were matched between experimental groups (10 Drd1a male mice: P19.4 \pm 0.2; 7 Drd1a female mice: P21.0 \pm 0.2; 4 Drd2 male mice: P19.8 \pm 0.5; 3 Drd2 female mice: P20.0 \pm 0.7; $p>0.05$ ). Approximately three neurons were recorded from each mouse. Mice were not weaned before experimental use and female vaginal opening had not occurred before experimental use. Pups were ear punched for identification and genotyping. Mice were housed in a temperature- and light-controlled room $\left(22 \pm 1^{\circ} \mathrm{C}, 40-45 \%\right.$ humidity, $12 \mathrm{~h}$ 
Table 1. Drd1a and Drd2 caudate-putamen medium spiny neuron properties compared across studies

\begin{tabular}{|c|c|c|c|c|c|c|c|c|c|}
\hline Property & $\begin{array}{c}\text { Kreitzer and } \\
\text { Malenka, } 2007^{\mathrm{a}}\end{array}$ & Gertler et al., 2008 & Cepeda et al., 2008 & Ade et al., $2008^{c}$ & Chan et al., 2012 & $\begin{array}{l}\text { Planert } \\
\text { et al., } 2013\end{array}$ & Planert et al., 2013 & Goodliffe et al., 2018 & $\begin{array}{c}\text { Current study, } \\
2019\end{array}$ \\
\hline Animal & Mice & Mice & Mice & Mice & Mice & Mice & Rats & Mice & Mice \\
\hline $\begin{array}{l}\text { MSN subtype } \\
\text { identification }\end{array}$ & $\begin{array}{l}\text { M4- or D2-eGFP } \\
\text { BAC } \\
\text { transgenic } \\
\text { mice }\end{array}$ & $\begin{array}{l}\text { D1 and D2 receptor- } \\
\text { eGFP BAC } \\
\text { transgenic } \\
\text { mice on an FVB } \\
\text { background }\end{array}$ & $\begin{array}{l}\text { D1 and D2 receptor- } \\
\text { eGFP BAC } \\
\text { transgenic mice }\end{array}$ & $\begin{array}{l}\text { D1 and D2 receptor- } \\
\text { eGFP BAC } \\
\text { transgenic mice } \\
\text { on a C57BL/6J } \\
\text { background }\end{array}$ & $\begin{array}{l}\text { D1 and D2 receptor- } \\
\text { eGFP BAC } \\
\text { transgenic mice } \\
\text { on either a FVB/ } \\
\text { NJ or C57BL/6J } \\
\text { background }\end{array}$ & $\begin{array}{l}\text { D1 receptor- } \\
\quad \text { eGFP } \\
\text { BAC } \\
\text { transgenic } \\
\text { mice }\end{array}$ & $\begin{array}{l}\text { Retrograde labeling } \\
\text { of striatonigral } \\
\text { MSNs }\end{array}$ & $\begin{array}{l}\text { D1 and D2 receptor- } \\
\text { eGFP BAC } \\
\text { transgenic mice } \\
\text { on a C57BL/6J } \\
\text { background }\end{array}$ & $\begin{array}{l}\text { B6 Cg-Tg (Drd1a- } \\
\text { tdTomato) } 6 \\
\text { Calak/J } \\
\text { hemizygous } \\
\text { mice ona } \\
\text { C57BL/6J } \\
\text { background }\end{array}$ \\
\hline Animal age & P20-P25 & P17-P70 & $\mathrm{P} 39.7 \pm 1.6$ & P16-P25 & P21-P35 & $\begin{array}{l}\mathrm{P} 15, \\
\mathrm{P} 21-\mathrm{P} 32\end{array}$ & P14-P19 & $\sim$ P365 & P17-P22 \\
\hline Animal sex & Not reported & Not reported & Not reported & $\begin{array}{l}\text { Male and female } \\
\text { data pooled } \\
\text { regardless of sex }\end{array}$ & Male & Not reported & Not reported & $\begin{array}{l}\text { Male and Female } \\
\text { data pooled } \\
\text { regardless of sex }\end{array}$ & $\begin{array}{l}\text { Male and Female } \\
\text { data analyzed } \\
\text { by sex }\end{array}$ \\
\hline $\begin{array}{l}\text { Resting membrane } \\
\text { potential }\end{array}$ & $\mathrm{D} 1=\mathrm{D} 2$ & $\mathrm{D} 1<\mathrm{D} 2$ & - & $\mathrm{D} 1=\mathrm{D} 2$ & - & $\mathrm{D} 1=\mathrm{D} 2$ & $\mathrm{D} 1=\mathrm{D} 2$ & $\mathrm{D} 1=\mathrm{D} 2$ & $\mathrm{D} 1=\mathrm{D} 2$ \\
\hline Rheobase & - & $\mathrm{D} 1>\mathrm{D} 2$ & - & - & - & $\mathrm{D} 1>\mathrm{D} 2$ & $\mathrm{D} 1>\mathrm{D} 2$ & $\mathrm{D} 1>\mathrm{D} 2$ & $\mathrm{D} 1>\mathrm{D} 2$ \\
\hline AP threshold & - & $\mathrm{D} 1=\mathrm{D} 2$ & $\mathrm{D} 1>\mathrm{D} 2$ & - & - & $\mathrm{D} 1=\mathrm{D} 2$ & $\mathrm{D} 1=\mathrm{D} 2$ & $\mathrm{D} 1>\mathrm{D} 2$ & $\mathrm{D} 1>\mathrm{D} 2$ \\
\hline AP amplitude & - & - & $\mathrm{D} 1=\mathrm{D} 2$ & - & - & - & - & $\mathrm{D} 1=\mathrm{D} 2$ & $\mathrm{D} 1=\mathrm{D} 2$ \\
\hline $\begin{array}{l}\text { AP amplitude change } \\
\text { from first to } \\
\text { second AP }\end{array}$ & - & - & - & - & - & $\mathrm{D} 1=\mathrm{D} 2$ & $\mathrm{D} 1>\mathrm{D} 2$ & - & - \\
\hline AP width & - & - & $\mathrm{D} 1=\mathrm{D} 2$ & - & - & $\mathrm{D} 1=\mathrm{D} 2$ & $\mathrm{D} 1=\mathrm{D} 2$ & - & $\mathrm{D} 1>\mathrm{D} 2$ \\
\hline AHP peak & - & - & $\mathrm{D} 1=\mathrm{D} 2$ & - & - & - & - & - & $\mathrm{D} 1=\mathrm{D} 2$ \\
\hline AHP time to Peak & - & - & - & - & - & - & - & - & $\mathrm{D} 1=\mathrm{D} 2$ \\
\hline $\begin{array}{l}\text { Frequency of evoked } \\
\text { action potentials/ } \\
\text { FI slope }\end{array}$ & $\mathrm{D} 1<\mathrm{D} 2$ & $\mathrm{D} 1<\mathrm{D} 2$ & - & $\mathrm{D} 1<\mathrm{D} 2$ & $\mathrm{D} 1<\mathrm{D} 2$ & $\mathrm{D} 1=\mathrm{D} 2$ & $\mathrm{D} 1=\mathrm{D} 2$ & - & $\mathrm{D} 1<\mathrm{D} 2$ \\
\hline $\begin{array}{l}\text { Linear range input } \\
\text { resistance }\end{array}$ & $\mathrm{D} 1=\mathrm{D} 2$ & $\mathrm{D} 1<\mathrm{D} 2$ & $\mathrm{D} 1=\mathrm{D} 2$ & $\mathrm{D} 1=\mathrm{D} 2$ & - & $\mathrm{D} 1=\mathrm{D} 2$ & $\mathrm{D} 1<\mathrm{D} 2$ & $\mathrm{D} 1=\mathrm{D} 2$ & $\mathrm{D} 1<\mathrm{D} 2$ \\
\hline $\begin{array}{l}\text { Rectified range input } \\
\text { resistance }\end{array}$ & - & - & - & - & - & $\mathrm{D} 1=\mathrm{D} 2$ & $\mathrm{D} 1=\mathrm{D} 2$ & - & $\mathrm{D} 1=\mathrm{D} 2$ \\
\hline $\begin{array}{l}\text { Inward rectification, } \\
\quad \%\end{array}$ & - & - & - & - & - & - & - & - & $\mathrm{D} 1=\mathrm{D} 2$ \\
\hline $\begin{array}{l}\text { Time constant of the } \\
\text { membrane }\end{array}$ & - & $\mathrm{D} 1>\mathrm{D} 2$ & $\mathrm{D} 1=\mathrm{D} 2$ & - & - & $\mathrm{D} 1=\mathrm{D} 2$ & $\mathrm{D} 1<\mathrm{D} 2$ & $\mathrm{D} 1<\mathrm{D} 2$ & $\mathrm{D} 1=\mathrm{D} 2$ \\
\hline Capacitance & - & $\mathrm{D} 1>\mathrm{D} 2$ & $\mathrm{D} 1=\mathrm{D} 2$ & - & - & - & - & - & $\mathrm{D} 1=\mathrm{D} 2$ \\
\hline sEPSC frequency & - & - & $\mathrm{D} 1<\mathrm{D} 2$ & - & - & - & - & - & - \\
\hline sEPSC amplitude & - & - & $\mathrm{D} 1=\mathrm{D} 2$ & - & - & - & - & - & - \\
\hline sEPSC kinetics & - & - & $\mathrm{D} 1=\mathrm{D} 2$ & - & - & - & - & - & - \\
\hline mEPSC frequency & $\mathrm{D} 1<\mathrm{D} 2$ & - & $\mathrm{D} 1<\mathrm{D} 2$ & - & - & - & - & $\mathrm{D} 1=\mathrm{D} 2$ & $\mathrm{D} 1=\mathrm{D} 2$ \\
\hline mEPSC amplitude & $\mathrm{D} 1=\mathrm{D} 2$ & - & $\mathrm{D} 1=\mathrm{D} 2$ & - & - & - & - & $\mathrm{D} 1=\mathrm{D} 2$ & $\mathrm{D} 1<\mathrm{D} 2$ \\
\hline mEPSC decay & $\mathrm{D} 1=\mathrm{D} 2$ & - & $\mathrm{D} 1=\mathrm{D} 2$ & - & - & - & - & - & $\mathrm{D} 1=\mathrm{D} 2$ \\
\hline mEPSC rise time & - & - & $\mathrm{D} 1<\mathrm{D} 2$ & - & - & - & - & - & $\mathrm{D} 1=\mathrm{D} 2$ \\
\hline $\mathrm{s} / \mathrm{mIPSC}$ frequency & - & - & - & $\mathrm{D} 1=\mathrm{D} 2$ & - & - & - & - & - \\
\hline s/mIPSC amplitude & - & - & - & $\mathrm{D} 1=\mathrm{D} 2$ & - & - & - & - & - \\
\hline $\mathrm{s} / \mathrm{mIPSC}$ decay & - & - & - & $\mathrm{D} 1=\mathrm{D} 2$ & - & - & - & - & - \\
\hline $\mathrm{s} / \mathrm{mIPSC}$ rise time & - & - & - & $\mathrm{D} 1=\mathrm{D} 2$ & - & - & - & - & - \\
\hline $\begin{array}{l}\text { Probability of } \\
\text { occurrence of } \\
\text { spontaneous } \\
\text { membrane } \\
\text { depolarization } \\
\text { after GABA } \\
\text { blockade }\end{array}$ & - & - & $\mathrm{D} 1<\mathrm{D} 2$ & - & - & - & - & - & - \\
\hline Paired-pulse ratio & $\mathrm{D} 1>\mathrm{D} 2$ & - & $\mathrm{D} 1<\mathrm{D} 2$ & - & - & - & - & - & - \\
\hline $\begin{array}{l}\text { AMPA-induced } \\
\text { current amplitude }\end{array}$ & - & - & $\mathrm{D} 1>\mathrm{D} 2$ & - & - & - & - & - & - \\
\hline NMDA/AMPA ratio & $\mathrm{D} 1<\mathrm{D} 2$ & - & - & - & - & - & - & - & - \\
\hline $\begin{array}{c}\text { Endocannabinoid- } \\
\text { mediated LTD }\end{array}$ & $\mathrm{D} 1<\mathrm{D} 2$ & - & - & - & - & - & - & - & - \\
\hline $\begin{array}{c}\text { Tonic GABA } A_{A} \text { current } \\
\text { and sensitivity to } \\
\text { GABA }_{A} \text { current }\end{array}$ & - & - & $\mathrm{D} 1<\mathrm{D} 2$ & $\mathrm{D} 1<\mathrm{D} 2$ & - & - & - & - & - \\
\hline
\end{tabular}

Only caudate-putamen MSN subtype electrophysiology studies in acute brain slice preparation experiments independent of variables such as dopamine depletion and psychostimulant exposure are included. This criteria a priori excludes studies that analyzed MSN subtype electrophysiological properties but did not directly compare D1 and D2 subtype groups (Day et al., 2006; Ade et al., 2011), or were performed in regions such as the nucleus accumbens (Ma et al., 2012; Cao et al., 2018). - , Did not measure; AP, action potential; AHP, afterhyperpolarization; FI, Frequency of evoked spikes to injected depolarization current; LTD, long-term depression.

aThe use of M4 eGFP labeling as equivalent to the D1 MSN subtype has been cautioned (Cepeda et al., 2008).

${ }^{b}$ This finding significant in some but not all analyses within this study.

${ }^{c} \mathrm{~A}$ number of studies from Vicini and colleagues have investigated GABA conductance between MSN subtypes; here we feature the initial report.

dPlanert et al. (2013) assessed rheobase using multiple analyses. The conclusion of all analyses was similar and is thus condensed here. 
light/dark cycle, lights on at 7:00 A.M.). All cages were washed polysulfone bisphenol $A$ free and were filled with bedding manufactured from virgin hardwood chips (Beta Chip, NEPCO) to avoid the endocrine disruptors present in corncob bedding (Markaverich et al., 2002; Mani et al., 2005; Villalon Landeros et al., 2012). Soy protein-free rodent chow (2020X, Teklad) and glass-bottle provided water were available ad libitum. All animals in these studies were maintained according to the applicable portions of the Animal Welfare Act and the U.S. Department of Health and Human Services Guide for the Care and Use of Laboratory Animals, and the study was approved by the Institutional Animal Care and Use Committee.

\section{Animal genotyping}

Mice genotyping was performed by Celplor using the following primers according to The Jackson Laboratory suggested protocol: transgene forward (forward primer, 12153, 5-CIT CTG AGG CGG AAA GAA CC-3), transgene reverse (reverse primer, 12154, 5-TTT CTG ATT GAG AGC ATT CG-3), PCR product length is $750 \mathrm{bp}$. The internal control was as follows: internal positive control forward (oIMR7338) CTA GGC CAC AGA ATT GAA AGA TCT, internal positive control reverse (olMR7339) GTA GGT GGA AAT TCT AGC ATC ATC C, PCR product length is $324 \mathrm{bp}$. PCR was performed according to the suggested protocol from The Jackson Laboratory: 1 cycle of $94^{\circ} \mathrm{C}$ for $2 \mathrm{~min}, 5$ cycles of $94^{\circ} \mathrm{C}$ for $30 \mathrm{~s}, 60-55^{\circ} \mathrm{C}$ touchdown ramp for $30 \mathrm{~s}$ and $72^{\circ} \mathrm{C}$ for $30 \mathrm{~s}, 25$ cycles of $94^{\circ} \mathrm{C}$ for $30 \mathrm{~s}, 55^{\circ} \mathrm{C}$ for $30 \mathrm{~s}$ and $72^{\circ} \mathrm{C}$ for $30 \mathrm{~s}$, followed by 1 cycle of $72^{\circ} \mathrm{C}$ for $5 \mathrm{~min}$.

\section{Acute brain slice preparation}

Brain slices for electrophysiological recordings were prepared following a previously published protocol (Dorris et al., 2014). Briefly, mice were deeply anesthetized with isoflurane gas and killed by decapitation. The brain was then dissected rapidly into ice-cold, oxygenated sucrose artificial cerebellum spinal fluid (s-ACSF) containing the following (in mM): 75 sucrose, $1.25 \mathrm{NaH}_{2} \mathrm{PO}_{4}, 3 \mathrm{MgCl}_{2}, 0.5$ $\mathrm{CaCl}_{2}, 2.4 \mathrm{Na}$ pyruvate, 1.3 ascorbic acid from SigmaAldrich, and $75 \mathrm{NaCl}, 25 \mathrm{NaHCO}_{3}, 15$ dextrose, $2 \mathrm{KCl}$ from Fisher. The osmolarity of the s-ACSF was between 295 and 305 mOsm, and pH was between 7.2 and 7.4. Coronal brain slices $(300 \mu \mathrm{m})$ were prepared using a vibratome and then incubated in regular ACSF containing the following (in mM): $126 \mathrm{NaCl}, 26 \mathrm{NaHCO}_{3}, 10$ dextrose, $3 \mathrm{KCl}, 1.25 \mathrm{NaH}_{2} \mathrm{PO}_{4}, 1 \mathrm{MgCl}_{2}, 2 \mathrm{CaCl}_{2}$ (295-305 mOsm, $\mathrm{pH} 7.2-7.4)$ for $30 \mathrm{~min}$ at $30 \pm 1^{\circ} \mathrm{C}$, and then at least 30 min at room temperature $\left(21-23^{\circ} \mathrm{C}\right)$. Slices were stored submerged in room temperature, oxygenated ACSF for up to $5 \mathrm{~h}$ after sectioning in a large volume bath holder.

\section{Electrophysiological recording}

Slices were allowed to rest at least $1 \mathrm{~h}$ after sectioning, and were then placed in a Zeiss Axioskop equipped with IR-DIC and fluorescent optics, a Dage IR-1000 video camera, and $10 \times$ and $40 \times$ lenses with optical zoom. Slices were superfused with oxygenated ACSF heated to $28 \pm 0.2^{\circ} \mathrm{C}$. Whole-cell patch-clamp recordings were used to record the electrical properties of fluorescently

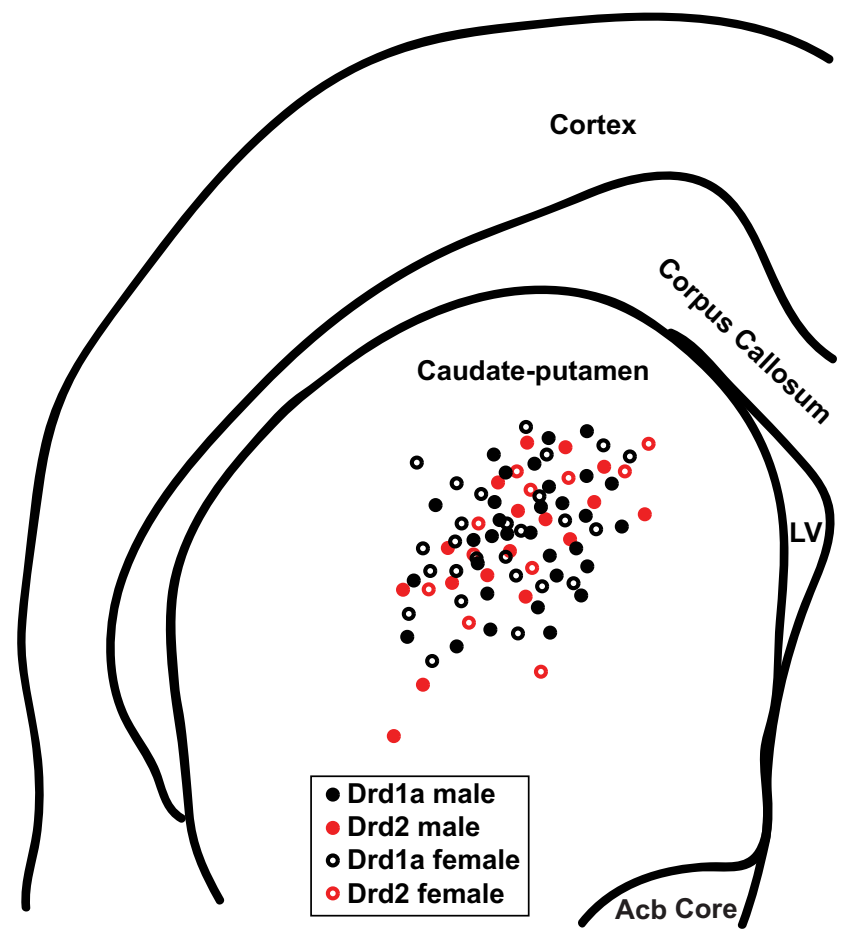

Figure 1. Whole-cell patch-clamped MSN location in the caudate-putamen of female and male Drd1a-tdTomato line 6 BAC transgenic mice. Drd1a males and females represent recordings from fluorescently-labeled Drd1a-positive MSNs. Drd2 males and females represent recordings from non-fluorescently labeled MSNs. LV, Lateral ventricle; AC, anterior commissure; ACB, nucleus accumbens.

labeled Drd1a and unlabeled Drd2 MSNs in the caudateputamen (Fig. 1). Caudate-putamen gross regional volume and cell density and soma size do not grossly vary by sex in rodents and humans (Meitzen et al., 2011; Wong et al., 2016). Glass patch electrodes contained the following solution (in mM): $115 \mathrm{~K} \mathrm{D}$-gluconate, $8 \mathrm{NaCl}, 2$ EGTA, $2 \mathrm{MgCl}_{2}$, 2 MgATP, 0.3 NaGTP, 10 phosphocreatine from Sigma-Aldrich, and 10 HEPES from Fisher $(285 \mathrm{mOsm}$, $\mathrm{pH} 7.2-7.4)$. Signals were amplified, filtered (2 kHz), and digitized $(10 \mathrm{kHz})$ with a MultiClamp 700B amplifier attached to a Digidata 1550 system and a personal computer using pClamp 10 software. Membrane potentials were corrected for a calculated liquid junction potential of $-13.5 \mathrm{mV}$. Using previously described procedures (Dorris et al., 2015), recordings were first made in current-clamp to assess neuronal action potential and passive membrane properties. MSNs were identified by their medium-sized somas, the presence of a slow ramping subthreshold depolarization in response to low-magnitude positive current injections, a hyperpolarized resting membrane potential more negative than $-65 \mathrm{mV}$, inward rectification, and prominent spike after hyperpolarization (O'Donnell and Grace, 1993; Belleau and Warren, 2000). After MSN identification and current-clamp recording, oxygenated ACSF containing both the $\mathrm{GABA}_{\mathrm{A}}$ receptor antagonist picrotoxin (PTX;150 $\mu \mathrm{M}$; Fisher) and the voltage-gated sodium channel blocker tetrodotoxin (TTX; $1 \mu \mathrm{m}$, Abcam Biochemicals) was applied to 
the bath solution to abolish GABAergic IPSC events and action potentials, respectively. Following an established protocol (Cao et al., 2016), once depolarizing current injection no longer generated an action potential after exposure to TTX and PTX, MSNs were voltage-clamped at $-70 \mathrm{mV}$ and miniature $\mathrm{mEPSCs}$ were recorded for at least $5 \mathrm{~min}$. In all experiments input/series resistance was monitored for changes and cells were excluded if resistance changed $>25 \%$.

\section{Data analysis}

Intrinsic electrophysiological properties, action potential and mEPSC characteristics were recorded and analyzed using pClamp 10. After break-in, the resting membrane potential was first allowed to stabilize for $\sim 1-2$ min, as in (Mu et al., 2010). Then, at least three series of depolarizing and hyperpolarizing current injections were applied to elicit basic neurophysiological properties. The electrophysiological properties measured followed previously described definitions (Dorris et al., 2015; Cao et al., 2016; Willett et al., 2016, 2018), which were based on those of Perkel and colleagues (Farries and Perkel, 2000, 2002; Farries et al., 2005; Meitzen et al., 2009). For each neuron, measurements were made of at least three action potentials generated from the minimum current injection necessary to elicit one or two action potentials. These measurements were then averaged to generate the reported action potential measurements for that neuron. For action potential measurements, only the first generated action potential was analyzed. Action potential threshold was defined as the first point of sustained positive acceleration of voltage $\left(\delta^{2} \mathrm{~V} / \delta t^{2}\right)$ that was also more than $3 \times \mathrm{SD}$ of membrane noise before the detected threshold (Baufreton et al., 2005). The slope of the linear range of the evoked firing rate to positive current curve (FI slope) was calculated from the first current stimulus that evoked an action potential to the first current stimulus that generated an evoked firing rate that persisted for at least two consecutive current stimuli. Input resistance in the linear, non-rectified range was calculated from the steady-state membrane potential in response to $-0.02 \mathrm{nA}$ hyperpolarizing injected current. Rectified range input resistance, inward rectification, and percentage inward rectification $(\mathrm{RRIR/IR} \times 100)$ was calculated using the most hyperpolarizing current injected into the MSNs, as previously described (Belleau and Warren, 2000). The membrane time constant was calculated by fitting a single exponential curve to the membrane potential change in response to $-0.02 \mathrm{nA}$ hyperpolarizing pulses. mEPSC frequency, amplitude, and decay were analyzed off-line using Mini Analysis (Synaptosoft, http://www.synaptosoft.com/MiniAnalysis/). Threshold was set as $5 \mathrm{pA}$, noise filter was set at $1000 \mathrm{~Hz}$, and accurate event detection was validated by visual inspection.

\section{Statistics}

Experiments were analyzed via a two-way ANOVA with a Tukey's multiple-comparisons post hoc test (Excel v2010; Microsoft; Prism v6.07, GraphPad Software). $p$ values $<0.05$ were considered a priori as significant. Values $6 \mathrm{SD}$ away from the mean were a priori excluded from analysis. Effect size was assessed using Cohen's $d$ value (Calin-Jageman, 2018). $d$ values are reported nu- merically and were classified a priori as small $(>0.20)$, medium ( $>0.50)$, and large ( $>0.80$; Cohen, 1977). Data are presented as mean \pm SEM.

\section{Results}

A total of $86 \mathrm{MSN}$ from the caudate-putamen of male and female B6 Cg-Tg (Drd1a-tdTomato) 6 Calak/J hemizygous mice were recorded for this study. Recorded MSNs were a priori sorted into four experimental groups: male tdTomato-labeled Drd1a-positive MSNs, female tdTomato-labeled Drd1a-positive MSNs, male tdTomatounlabeled MSNs, and female tdTomato-unlabeled MSNs. MSNs unlabeled by tdTomato fluorescence nearly exclusively comprise the Drd2-positive MSN subtype, including during the developmental age and striatal region assessed in this study (Ade et al., 2011; Enoksson et al., 2012; Thibault et al., 2013). tdTomato-unlabeled MSNs have rare $(\sim 1.6 \%)$ contamination with Drd1a-positive MSNs. Thus, for convenience in this study we refer to all tdTomato-unlabeled MSNs as Drd2 MSNs, with the full acknowledgment that this designation is putative.

\section{Action potential properties}

To test the hypothesis that action potential properties differed across MSN subtype and animal sex, MSNs were current-clamped and injected with increasing amounts of depolarizing current to elicit action potential generation (Fig. $2 A$ ). The resting membrane potential, rheobase, action potential threshold, width, amplitude, action potential afterhyperpolarization peak amplitude and time to afterhyperpolarization peak amplitude were assessed (Table 2). MSNs exhibited differences between subtypes or interactions between subtype and sex in several attributes, including the resting membrane potential (Fig. 2B). Compared between groups, the resting membrane potential of male Drd1a MSNs was hyperpolarized compared with male Drd2 MSNs ( $p<0.01 ; d=0.86$ ), but not between female Drd1a MSNs compared with female Drd2 MSNs ( $p$ $>0.05, d=0.42$ ). Rheobase, or the minimum current sufficient for eliciting action potential generation, was increased in Drd1a MSNs compared with Drd2 MSNs (Fig. $2 C)$. Compared between groups, the rheobase of male Drd1a MSNs differed from male and female Drd2 MSNs $(p<0.05, d=0.74 ; p<0.05, d=0.77$; respectively). The action potential threshold was hyperpolarized in Drd1a MSNs compared with Drd2 MSNs (Fig. 2D). Compared between groups, the action potential threshold of female Drd1a MSNs differed from female Drd2 MSNs $(p<0.01, d=1.00)$, but not between male Drd1a MSNs and male Drd2 MSNs ( $p>0.05, d=0.05)$. The action potential width of Drd1a MSNs was longer compared with Drd2 MSNs (Fig. 2E). Compared between groups, the action potential width of male Drd1a MSNs was increased compared with male Drd2 MSNs $(p<$ $0.01, d=1.24)$, but not between female Drd1a MSNs and female Drd2 MSNs ( $p>0.05, d=0.03$ ). Considering other passive properties, no differences were detected between MSN subtype and sex in action potential amplitude, action potential afterhyperpolarization peak amplitude and time to afterhyperpolarization peak amplitude (Table 2). These differences in action potential properties indi- 
A

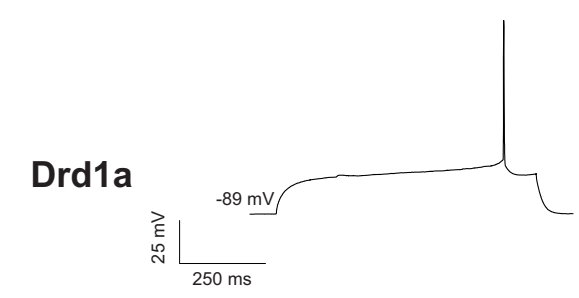

Drd2
Female
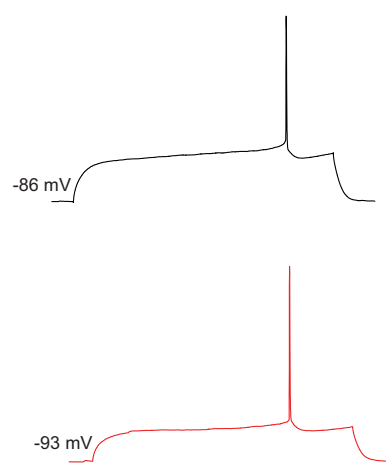

B

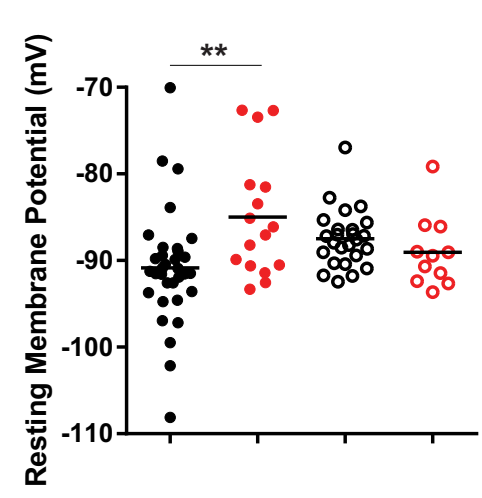

C

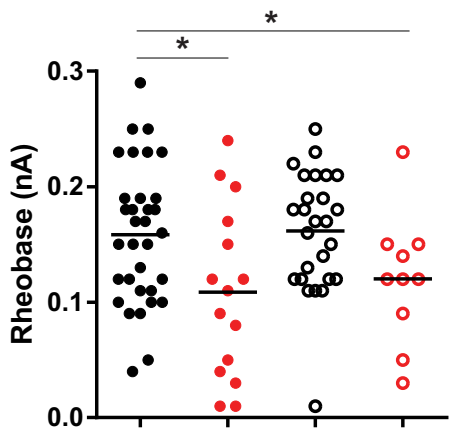

E

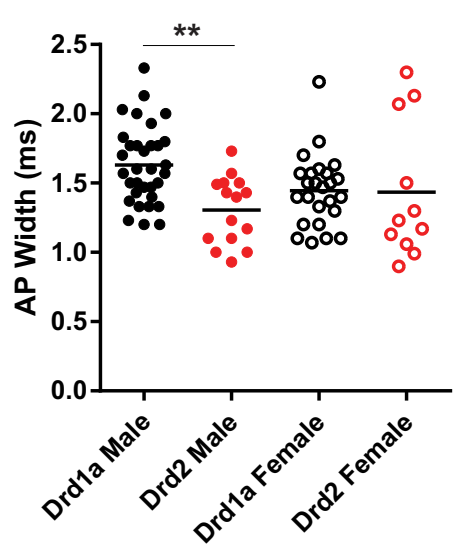

Figure 2. Action potential rheobase, threshold, and width vary by MSN subtype. $\boldsymbol{A}$, Voltage response of male and female Drd1a and Drd2 MSN subtypes to a depolarizing rheobase current injection. $\boldsymbol{B}$, Resting membrane potential exhibited greater diversity in male Drd1A MSNs. C, Action potential rheobase is increased in Drd1a MSNs compared with Drd2 MSNs. $\boldsymbol{D}$, Action potential threshold is depolarized in Drd1a MSNs compared with Drd2 MSNs, and interacts with sex. $\boldsymbol{E}$, Action potential width is longer in Drd1a MSNs compared with Drd2 MSNs, and interacts with sex. AP, Action potential. $* p<0.05, * * p<0.01$.

cate that Drd1a MSNs are less likely to generate an action potential at low magnitudes of injected depolarizing current than are Drd2 MSNs.

\section{Intrinsic excitability and action potential generation rates}

These differences between MSN subtype rheobase, action potential threshold, width, and time to first action potential properties indicate that overall MSN excitability may also differ by subtype (Fig. $3 A$ ). To assess this, we began by analyzing the frequency of action potentials evoked by depolarizing current injections. Action potential firing rates evoked by depolarizing current injections were visibly decreased in Drd1a compared with Drd2 MSNs in both males and females (Fig. 3B). To further probe the relationship between MSN subtype and action potential generation, we quantified the slope of the evoked firing rate to positive current curve (FI slope). FI slope differed by subtype but not sex, with Drd1a MSNs exhibiting decreased excitability compared with Drd2 MSNs (Fig. $3 C)$. Compared between groups, the FI slope of male Drd1a MSNs differed from male Drd2 MSNs $(p<0.01, d$ $=0.96)$. Female Drd1A MSNs differed from male Drd2 
Table 2. Electrophysiological properties of male and female Drd1a and Drd2 mouse caudate-putamen medium spiny neurons

\begin{tabular}{lll}
\hline Property & Drd1a & Drd2 \\
Resting potential, $\mathrm{mV}$ & Male: $-90.9 \pm 1.2^{a}$ & Male: $-85.0 \pm 1.8^{b}$ \\
& Female: $-87.5 \pm 0.7^{a, b}$ & Female: $-89.0 \pm 1.2^{a, b}$
\end{tabular}

Statistics $(F, p)$

Female: $-87.5 \pm 0.7^{a, b}$

Female: $-89.0 \pm 1.2^{a, b}$

Interaction: $F_{(1,82)}=8.7 ; p=0.004$

Sex: $F_{(1,82)}=0.1 ; p=0.75$

Subtype: $F_{(1,82)}=2.8 ; p=0.10$

post hoc: Tukey's

Rheobase, $\mathrm{nA}$

AP threshold, mV

AP amplitude, mV

Male: $68.8 \pm 2.1$

Female: $69.5 \pm 2.9$

Male: $1.63 \pm 0.05^{\mathrm{a}}$

Female: $1.45 \pm 0.05^{\mathrm{a}, \mathrm{b}}$

AP width at half-peak, ms

AHP peak, mV

-

AHP time to peak, ms

Female: $26.3 \pm 1.6$

Male: $-8.9 \pm 0.4$

Female: $-11.0 \pm 0.7$

Male: $-9.8 \pm 0.8$

Female: $-9.2 \pm 0.7$

Male: $31.8 \pm 3.4$

Female: $32.5 \pm 3.2$

Male: $192.5 \pm 10.4^{\mathrm{a}}$

Female: $164.0 \pm 12.8^{\mathrm{a}}$

Male: $278.7 \pm 28.9^{b}$

Female: $242.0 \pm 23.0^{b}$

FI slope, $\mathrm{Hz} / \mathrm{nA}$
Male: $32.2 \pm 1.3$

Interaction: $F_{(1,82)}=0.4 ; p=0.52$

Sex: $F_{(1,82)}=0.4 ; p=0.54$

Subtype: $F_{(1,82)}=12.3 ; p=0.0007$ post hoc: Tukey's

Interaction: $\boldsymbol{F}_{(1,81)}=\mathbf{7 . 2} ; \boldsymbol{p}=\mathbf{0 . 0 0 8 7}$ Sex: $F_{(1,81)}=0.01 ; p=0.90$

Subtype: $F_{(1,81)}=8.0 ; p=0.0058$ post hoc: Tukey's

Interaction: $F_{(1,81)}=2.3 ; p=0.13$

Sex: $F_{(1,81)}=3.1 ; p=0.08$

Subtype: $F_{(1,81)}=3.0 ; p=0.09$

Interaction: $\boldsymbol{F}_{(1,80)}=\mathbf{4 . 7} ; \boldsymbol{p}=\mathbf{0 . 0 3 3 9}$

Sex: $F_{(1,80)}=0.1 ; p=0.7052$

Subtype: $F_{(1,80)}=5.3 ; p=0.0234$

post hoc: Tukey's

Interaction: $F_{(1,80)}=3.5 ; p=0.0654$

Sex: $F_{(1,80)}=0.8 ; p=0.37$

Subtype: $F_{(1,80)}=0.2 ; p=0.69$

Interaction: $F_{(1,81)}=2.1 ; p=0.15$

Sex: $F_{(1,81)}=1.4 ; p=0.24$

Subtype: $F_{(1,81)}=1.6 ; p=0.21$
Male: $102.1 \pm 5.8^{\mathrm{a}}$

Female: $93.6 \pm 6.6^{\mathrm{a}}$

Male: $141.0 \pm 19.2^{b}$

Female: $109.8 \pm 18.3^{a, b}$

Interaction: $F_{(1,81)}=0.1 ; p=0.82$

Sex: $F_{(1,81)}=3.4 ; p=0.0708$

Subtype: $F_{(1,81)}=21.2 ; p<0.0001$

post hoc: Tukey's

Interaction: $F_{(1,78)}=1.1 ; p=0.30$

Sex: $F_{(1,78)}=2.9 ; p=0.09$

Subtype: $F_{(1,78)}=6.3 ; p=0.0138$

post hoc: Tukey's

Rectified range input resistance, $\mathrm{M} \Omega$

Male: $83.4 \pm 4.7$

Female: $83.9 \pm 8.6$

Male: $112.0 \pm 17.7$

Female: $83.1 \pm 11.7$

Interaction: $F_{(1,79)}=2.0 ; p=0.16$

Sex: $F_{(1,79)}=1.9 ; p=0.17$

Subtype: $F_{(1,79)}=1.8 ; p=0.18$

Inward rectification, \%

Male: $82.3 \pm 1.3$

Female: $81.0 \pm 1.8$

Male: $80.8 \pm 4.3$

Female: $79.2 \pm 3.3$

Male: $14.6 \pm 3.2$

Female: $9.9 \pm 1.9$

Male: $10.3 \pm 0.8$

Male: $94.4 \pm 11.2$

Female: $91.2 \pm 8.5$

Female: $99.0 \pm 7.0$

Male: $2.0 \pm 0.5$

Male: $1.9 \pm 0.2$

Female: $1.9 \pm 0.2$

Female: $1.4 \pm 0.4$

Male: $15.9 \pm 0.4^{\mathrm{a}}$

mEPSC amplitude, $\mathrm{pA}$
Male: $17.7 \pm 1.1^{a, b}$

Female: $20.7 \pm 1.5^{b}$
Interaction: $F_{(1,79)}=0.0 ; p=0.93$

Sex: $F_{(1,79)}=0.3 ; p=0.57$

Subtype: $F_{(1,79)}=0.4 ; p=0.52$

Interaction: $F_{(1,82)}=2.9 ; p=0.09$

Sex: $F_{(1,82)}=1.2 ; p=0.28$

Subtype: $F_{(1,82)}=1.6 ; p=0.20$

Interaction: $F_{(1,78)}=0.1 ; p=0.74$

Sex: $F_{(1,78)}=0.4 ; p=0.55$

Subtype: $F_{(1,78)}=1.0 ; p=0.31$

Interaction: $F_{(1,47)}=0.9 ; p=0.33$

Sex: $F_{(1,47)}=1.2 ; p=0.29$

Subtype: $F_{(1,47)}=0.3 ; p=0.58$

Interaction: $\boldsymbol{F}_{(1,47)}=\mathbf{5 . 2} \boldsymbol{p}=\mathbf{0 . 0 2 7 0}$

Sex: $F_{(1,47)}=2.1 ; p=0.1498$

Subtype: $\boldsymbol{F}_{(1,47)}=20.4 ; p<0.0001$ post hoc: Tukey's

Interaction: $F_{(1,47)}=2.6 ; p=0.11$

Sex: $F_{(1,47)}=0.1 ; p=0.76$

Subtype: $F_{(1,47)}=0.0 ; p=0.95$

Values are mean \pm SEM. Bold font indicates statistical significance. Different superscript letters denote significant differences detected by a Tukey's post hoc test. AP, action potential; AHP, afterhyperpolarization; FI, frequency of evoked spikes to injected depolarization current. 
A
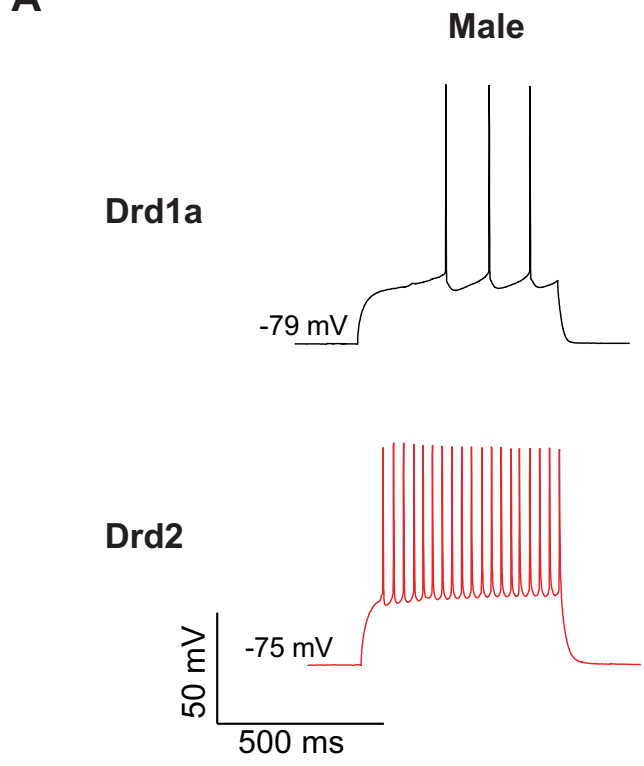

B

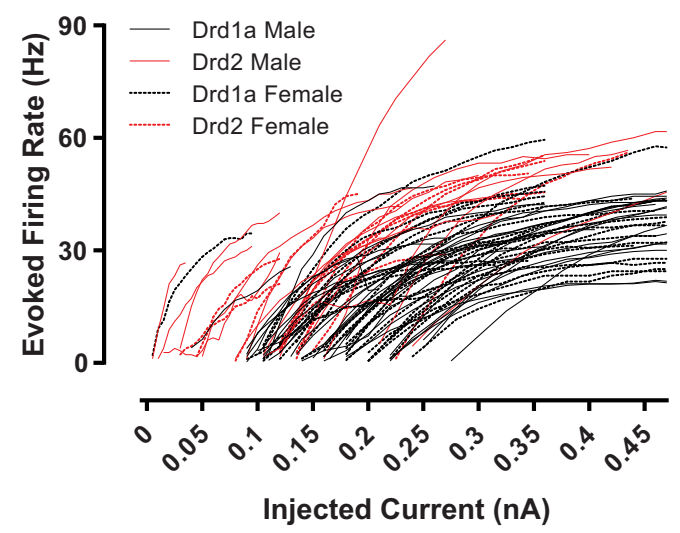

Female
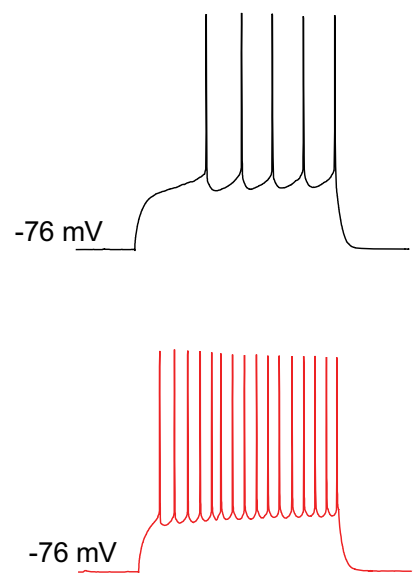

C

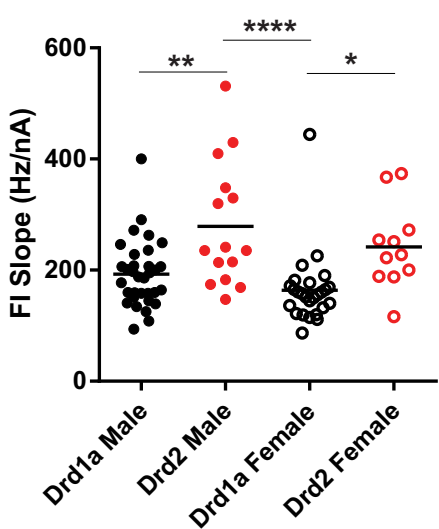

Figure 3. Action potential firing rates evoked by depolarizing current injections vary by MSN subtype. $\boldsymbol{A}$, Voltage response of male and female Drd1a and Drd2 MSN subtypes to a depolarizing post-rheobase current injection. $\boldsymbol{B}$, Drd1a MSNs exhibited decreased action potential firing rates evoked by depolarizing current injections compared with Drd2 MSNs. C, The slope of the evoked action potential to depolarizing current injection curve (FI slope) differed by MSN subtype, with Drd2 MSNs exhibiting increased excitability compared with Drd1a MSNs. FI slope, Slope of the evoked action potential to depolarizing current injection curve. $* p<0.05, * * p<$ $0.01, * * * * p<0.0001$.

MSNs $(p<0.0001, d=1.25)$ and female Drd2 MSNs $(p<$ $0.05, d=1.10)$. These data indicate that excitability robustly differs between MSN subtypes.

\section{Passive membrane properties}

To test the hypothesis that MSN passive electrophysiological properties differed by subtype and sex, a series of increasingly negative current pulses were injected into individual neurons (Fig. 4A). MSN subtypes exhibited differences in input resistance across both the linear and rectified ranges (Fig. 4B). Input resistance in the linear and rectified ranges, percentage inward rectification, time constant of the membrane, and capacitance were analyzed (Table 2). Linear range input resistance was largely decreased in Drd1a MSNs compared with Drd2 MSNs (Fig. 4C). Compared between groups, the linear range input resistance of male Drd1a MSNs differed from male Drd2 MSNs ( $p<0.05 . d=0.67)$, but did not differ between female Drd1a MSNs and female Drd2 MSNs ( $p$
$>0.05, d=0.34)$. Male Drd2 MSNs also differed from female Drd1a MSNs ( $p<0.05, d=0.83$ ). Rectified range input resistance did not differ between MSN subtypes (Fig. 4D) or other measures of inward rectification (Table 2). Considering other passive properties, no differences were detected between MSN subtype or sex in the time constant of the membrane, and capacitance (Table 2). Collectively, these analyses indicate that input resistance varies between MSN subtypes, with no differences in other passive membrane properties.

\section{mEPSC properties}

We voltage-clamped 18 male and 17 female Drd1a MSNs and 10 male and 6 female Drd2 MSNs at $-70 \mathrm{mV}$ and recorded mEPSCs in the presence of TTX and PTX (Fig. 5A). mEPSC frequency, amplitude and decay were analyzed (Table 2). mEPSC amplitude was increased in 
A
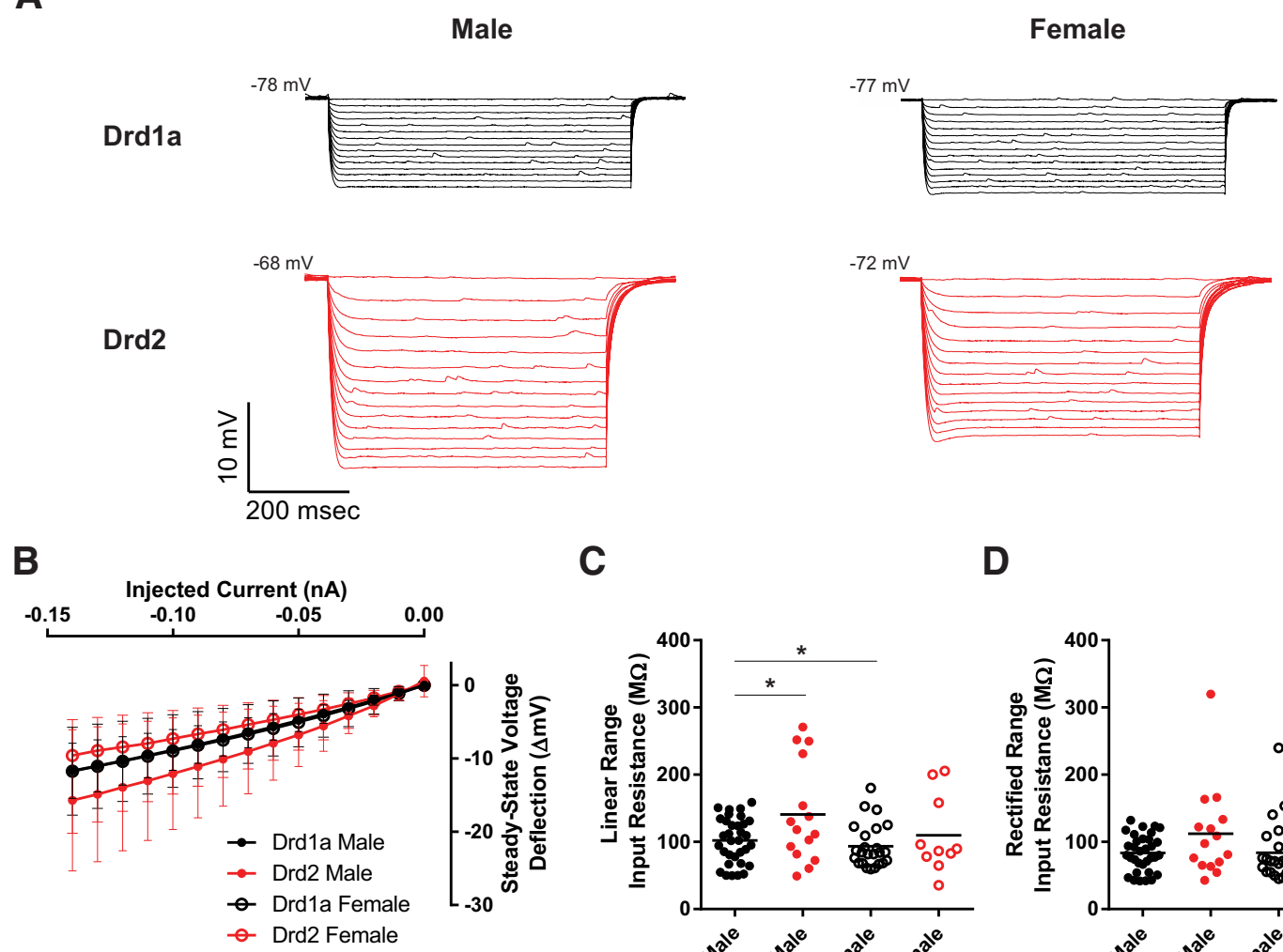

C

D
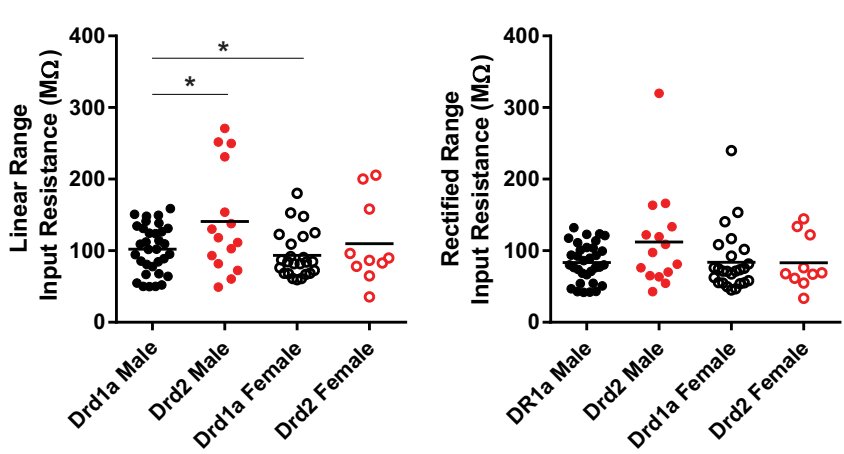

Figure 4. Input resistance varies by MSN subtype. A, Voltage response of male and female Drd1a and Drd2 MSN subtypes to a series of increasingly negative current injections ( $-0.01 \mathrm{nA}$ current steps). $\boldsymbol{B}$, Injected negative current to steady-stage voltage deflection curve (I-V curve). Legend, Red solid circles with red line, Drd1a males; black solid circles with black line, Drd2 males; red open circles with red line, Drd1a females; black open circles with black line, Drd2 females. $\boldsymbol{C}$, Input resistance in the linear range is moderately decreased in Drd1a MSNs compared with Drd2 MSNs. $\boldsymbol{D}$, Input resistance in the rectified range does not differ between subtypes. $* p<0.05$.

Drd1a MSNs compared with Drd2 MSNs (Fig. 5B). Compared between groups, the mEPSC amplitude of male Drd1a MSNs differed from female Drd2 MSNs $(p$ $<0.01, d=0.82)$ but not male Drd2 MSNs $(p>0.05, d$ $=0.67)$. The mEPSC amplitude of female Drd1a MSNs differed from female Drd2 MSNs $(p<0.001, d=1.74)$. mEPSC decay did not differ between MSN subtype or sex (Fig. 5C). Likewise, mEPSC frequency did not differ between MSN subtype or sex (Fig. 5D). These data indicate that mEPSC amplitude differs between MSN subtypes.

\section{Discussion}

MSNs form at least two major pathways depending on their dopaminergic receptor and neuropeptide expression, electrophysiological properties, where they project, and ultimately their effect on behavior. The caudateputamen MSNs of the direct pathway predominantly express D1-dopamine receptors, contain substance $\mathrm{P}$ and dynorphin, project to the basal ganglia output nuclei, and stimulate downstream behavioral output. Indirect pathway MSNs express D2-dopamine receptors, contain encephalin, project to the lateral globus pallidus, and lead to inhibition of downstream behavioral output. This study comprehensively evaluates mouse caudate-putamen MSN subtype electrophysiological properties, extending previous studies that targeted a smaller battery of electrical properties and that were performed solely in males or mice of unknown sex (Table 1). Electrophysiological properties differed between MSN subtypes, with Drd2 MSNs exhibiting increased intrinsic excitability compared with Drd1a MSNs, which is indicated most notably by differences in rheobase, action potential threshold, input resistance in the linear range, and increased FI slope. Interestingly, this robust set of properties exhibits varying degrees of consistence with previous literature on MSN subtype electrophysiology, and select electrophysiological properties showed statistical interactions between subtype and biological sex.

The detected increase in excitability in Drd2 MSNs is generally consistent with previous studies of MSN subtypes in rodents across striatal regions, although there are subtle differences depending on the assessed electrophysiological metric and perhaps age (Onn et al., 1994a, b,c; Venance and Glowinski, 2003; Kreitzer and Malenka, 2007; Ade et al., 2008; Cepeda et al., 2008; Gertler et al., 2008; Chan et al., 2012; Ma et al., 2012; Planert et al., 
A

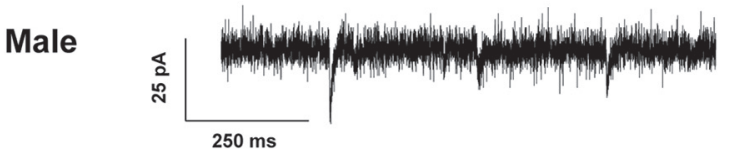

Female
Drd1a

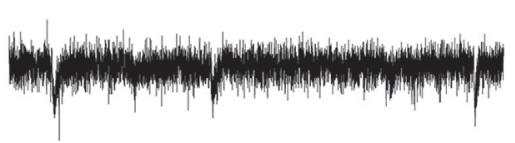

Drd2

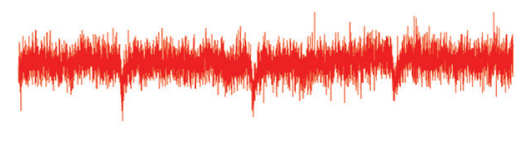

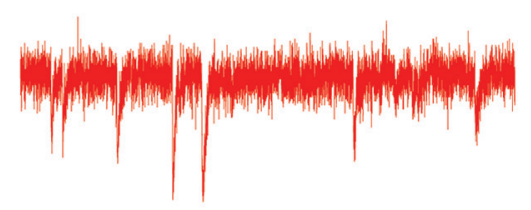

B

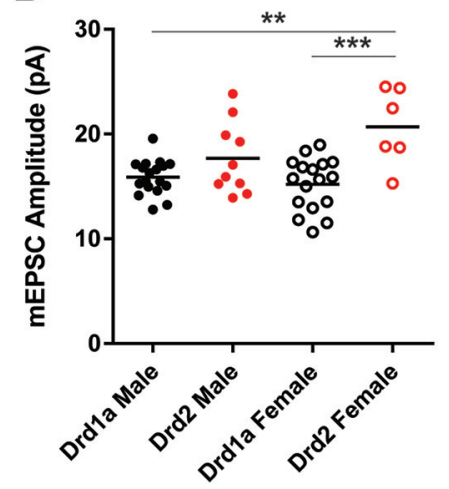

C

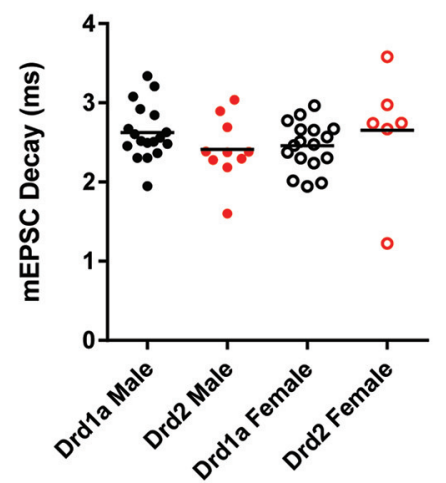

D

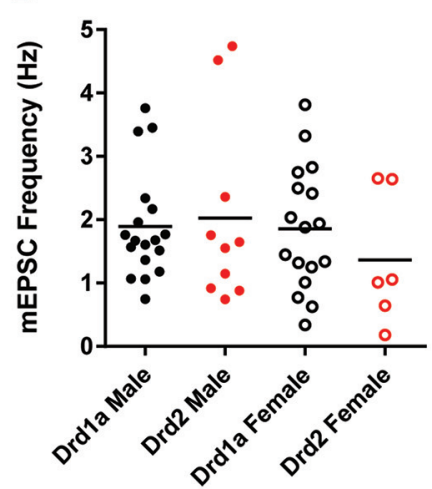

Figure 5. mEPSC properties vary by MSN subtype. A, mEPSCs recorded from male and female Drd1a and Drd2 MSN subtypes. MSNs were voltage-clamped at $-70 \mathrm{mV}$ and $\mathrm{mEPSCs}$ were recorded in the presence of TTX and PTX to block voltage-gated sodium channels and GABAergic synaptic activity, respectively. $\boldsymbol{B}$, mEPSC amplitude was increased in Drd1a MSNs compared with Drd2 MSNs. $\boldsymbol{C}$, mEPSC decay did not differ by subtype or sex. $\boldsymbol{D}$, mEPSC frequency did not differ by subtype or sex. $* * p<0.01, * * * p<0.001$.

2013; Reig and Silberberg, 2014; Maurice et al., 2015; Cao et al., 2018; Goodliffe et al., 2018). Perhaps the most consistent metric indicating increased excitability in Drd2 MSNs compared with Drd1a MSNs is the decreased rheobase in Drd2 MSNs. Every study that has assessed this property has detected this difference, despite using varying protocols and electrophysiological methods. From an electrophysiological perspective, differences in rheobase are rarely the sole electrophysiological difference between neuron types. Generally, a shift in rheobase is accompanied by concomitant changes in properties such as resting membrane potential, input resistance in the linear range, and/or action potential threshold. For instance, Gertler et al. (2008) detected changes in rheobase accompanied by changes in resting membrane potential and input resistance, but not action potential threshold. Planert et al. (2013) detected changes in rheobase accompanied by a change in input resistance, but not action potential threshold or resting membrane potential in rats but not mice. Cepeda et al. (2008) did not assess rheobase, but did detect a difference in action potential threshold. The current study detected a difference in rheobase accompanied by changes in action potential threshold and input resistance, supporting a model where the decreased rheobase values in Drd2 MSN subtypes is largely driven by a hyperpolarized action potential threshold and an increased input resistance. The increase in excitability observed in Drd2 MSNs could ultimately translate to a decrease in behavioral output.
However, this particular interpretation is highly tentative given that MSNs make complex calculations between dopamine, glutamate, intrinsic properties, and other neuromodulators. Interestingly, we detected an interaction between MSN subtype and sex in resting membrane potential and action potential threshold. Thus, it is possible that the reason why the results of our study differ from those of Gertler et al. (2008) is because of the use of animals of undetermined sex in that study.

Regarding excitatory synaptic input, the current study detected increased mEPSC amplitude in Drd2 MSN subtypes compared with Drd1a MSN subtypes. To our knowledge, this is the first indication that $\mathrm{mEPSC}$ amplitude can differ by MSN subtype (Table 1). This may be because of a variance and power interaction, although previous studies of MSN subtypes used similar experimental $N$. This finding does align with previous research which detected large amplitude AMPA-mediated synaptic events in Drd2 MSNs that were not seen in Drd1a MSNs (Cepeda et al., 2008). The recording conditions under which the mEPSCs were assessed in this study eliminate non-AMPA-mediated currents (Proaño et al., 2018). A number of factors could potentially mediate this difference in mEPSC amplitude, including morphologic differences and/or differences in AMPA receptor number or subunit composition (Tallaksen-Greene and Albin, 1996; Vorobjev et al., 2000). Supporting this, there is evidence that the size of corticostriatal presynaptic terminals is larger on Drd2 MSN spines compared with Drd1a MSN spines (Lei et al., 
2004). One possibility why previous studies did not detect a significant difference in mEPSC amplitude is because the effect size for this particular attribute is larger in females compared with males. Previous studies either only tested males or did not report sex, or sex-specific findings. Following this, two previous studies detected a greater sEPSC and mEPSC frequency in caudateputamen Drd2 MSNs compared with Drd1a MSNs that is not accompanied by differences in amplitude or decay (Kreitzer and Malenka, 2007; Cepeda et al., 2008). However, this literature is mixed because Cepeda et al. (2008) detected a difference in mEPSC rise time, Day et al. (2006) did not detect a difference in mEPSC frequency in prepubertal animals, and Goodliffe et al. (2018) did not detect a difference in mEPSC frequency in adult animals. It is possible that this variability in findings is in some part explained by the neglect or overrepresentation of one sex compared with another.

There are other factors which may also play a role, including animal age. Most studies of MSN subtype properties used mice that were between P17 and P30 (Table 1). During these periods, various levels of MSN synaptic maturation are occurring, which could contribute to variance in mEPSC properties (Tepper et al., 1998; Uryu et al., 1999). Gertler et al. (2008) used a wide variety of ages to demonstrate that MSN subtype intrinsic properties differ before puberty, but the study did not assess excitatory synaptic properties. Goodliffe et al. (2018) assessed at a much older age ( P365), and found differences in intrinsic properties but not mEPSC properties (Table 1). Thus, our assessment of the literature is that there is ample evidence for differences in MSN subtype electrophysiological properties prepuberty, but that there is a real need for further studies in adult animals, especially within the context of excitatory synapse properties, sex-specific hormone dynamics, and animal sex, especially because the current study is the only available analysis by sex in mouse caudate-putamen.

Similarly, Drd1a and Drd2 MSN subtypes display different sensitivities to neuromodulators such as dopamine during prepubertal development (Lieberman et al., 2018). Indeed, it has been documented in multiple striatal regions that dopamine receptor expression and/or action shows sex-specific effects during puberty (Andersen et al., 1997, 2002; Kopec et al., 2018). Interestingly, excitatory currents generated by pyramidal tract stimulation show an increased amplitude in Drd1a MSNs compared with Drd2 MSNs in adult male and female mice that were not analyzed with regard to sex (Kress et al., 2013). In in vivo experiments in adult female mice, Drd1a MSNs were found to be more responsive to excitatory glutamatergic input compared with Drd2 MSNs (Escande et al., 2016). However, this study used the line 5 Drd1a-tdTomato BAC-transgenic mice, which express properties such as an X-linked inheritance pattern and undefined mammary glands that reduces this strain's utility for assessing interactions between MSN subtypes and sex (Shuen et al., 2008; Ade et al., 2011). Subtype-specific differences in the development of glutamatergic and dopaminergic inputs onto MSNs in the caudate-putamen require further research, especially in the context of biological sex, environmental stimuli, and animals beyond mice.

The strain and/or species is also a relevant factor in explaining differences in MSN subtype electrophysiological properties across studies. For instance, multiple strains of transgenic mice have been used across studies which have used a variety of means to determine MSN subtype identity. Cepeda et al. (2008), Gertler et al. (2008), and the current study all targeted Drd1a or Drd2 expression to identify MSN subtypes (albeit with different transgenic strategies), whereas other studies have used different targets such as the muscarinic M4 receptor locus which labels striatonigral MSNs (Kreitzer and Malenka, 2007). There is some evidence that there is incomplete overlap between M4 and Drd1a dopamine receptors which may contribute to variance in detected electrophysiological properties, including SEPSC frequency between M4 and D1 cells (Bernard et al., 1992; Cepeda et al., 2008). Here we used the B6 Cg-Tg (Drd1a-tdTomato) 6 Calak/J hemizygous mice (line 6). We chose this strain because of its established high specificity, in that tdTomato-labeled MSNs almost exclusively consist of Drd1a MSNs, and that tdTomato-unlabeled MSNs exhibit only $\sim 1.6 \%$ contamination with Drd1a MSNs (Ade et al., 2011; Enoksson et al., 2012; Thibault et al., 2013). Furthermore, the tdTomato label is easily detected using standard fluorescent microscopy, optimizing differentiation for whole-cell patch-clamp. Although the line 6 version of this transgenic mouse line does not show the obvious confounds for sex research that the line 5 version displays, including the $\mathrm{X}$-linked inheritance pattern and undefined mammary glands, caution is always necessary with any transgenic mouse line that targets dopamine receptors. It is possible that transgenes targeting dopamine receptors subtly disrupt sexual differentiation, especially given the long documented and recently reaffirmed sex differences and hormone-sensitivity of the dopaminergic system in both rats and mice (Di Paolo, 1994; Becker, 1999; Calipari et al., 2017).

Independent of sex, other mouse lines with transgenic manipulations of the dopamine system by attaching fluorophores have shown aberrant striatal-mediated behaviors, especially when strain and genetic homozygosity were not carefully monitored (Kramer et al., 2011; Chan et al., 2012). We raise this possibility neither to argue that transgenic mice in general are not useful for neuroscience research nor for understanding the effects of sex and steroid sex hormones. Several mouse models have made critical contributions to our understanding of sexual differentiation, most notably the four core genotypes (De Vries et al., 2002), including as applied to the caudateputamen (Chen et al., 2009). Rather, we argue that the specific disadvantages and advantages of each research animal should be thoughtfully considered, especially for studies of the impact of natural variables such as sex on individual neuron function. There is no "one size fits all" mouse strain, just as there is no "one size fits all" strain of rat or any other research animal, echoing arguments presented by many investigators in diverse contexts (Beach, 1950; Krebs, 1975; Young et al., 2013; Brenowitz and 
Zakon, 2015; Ellenbroek and Youn, 2016; Klinck et al., 2017; Remage-Healey et al., 2017). Regarding species differences, to our knowledge, there is only one study that has assessed MSN subtype electrophysiological properties in the caudate-putamen of a species other than mice. Similar to the current study in mice, Planert et al. (2013) found a difference in rheobase and related properties in prepubertal rats of unreported sex. Synaptic properties were not assessed.

Further complicating interpretation was the number of interactions between MSN subtype and sex detected by the current study. Given that animals were assessed before pubertal onset but after the perinatal critical period for hormone-induced organization of the neural substrate, it is possible that these sex differences were generated through some combination of masculinizing/defeminizing hormone action, genes, or epigenetics. All three of these mechanisms are potentially at work in the caudateputamen and could contribute to the MSN subtype and sex interactions observed here (Chen et al., 2009; Cao et al., 2016). Previous studies in mice used only males, animals of unreported sex, or animals of both sex sexes that were pooled for data analysis. This lack of consideration of biological sex is problematic given the longknown sex differences in striatal mediated behaviors, disorders, MSN properties, and neuromodulator systems such as dopamine (Mermelstein et al., 1996; McLean and Anderson, 2009; Carroll and Anker, 2010; Young and Korszun, 2010; Becker and Chartoff, 2018; Meitzen et al., 2018). Although this work has predominantly been performed in rats, importantly, adult mice exhibit sex differences in striatal gene expression and function in both the caudate-putamen and nucleus accumbens (Chen et al., 2009; Calipari et al., 2017). The current study detected an interaction in action potential threshold, which was also found to differ by sex in prepubertal rats (Dorris et al., 2015). Other electrophysiological properties also differed by sex in rats, including the frequency of evoked action potentials to injected current and the action potential afterhyperpolarization, but were not found to differ by the current study in mice. This difference between mice and rats may be because of a number of potential factors, including but not limited to variance between inbred and outbred rodent strains, overall species differences and the effects of domestication, MSN subtype sampling bias, developmental trajectory, environmental factors such as stress, and/or location within the caudate-putamen or striatum as a whole. For a phylogenetically ancient and highly conserved brain region such as the caudateputamen, it will be particularly interesting to investigate the intersecting roles of subtype, development, and biological sex in influencing MSN electrophysiological properties across a wide range of animals with divergent reproductive behaviors.

\section{References}

Ade KK, Janssen MJ, Ortinski PI, Vicini S (2008) Differential tonic GABA conductances in striatal medium spiny neurons. J Neurosci 28:1185-1197.

Ade KK, Wan Y, Chen M, Gloss B, Calakos N (2011) An improved BAC transgenic fluorescent reporter line for sensitive and specific identification of striatonigral medium spiny neurons. Front Syst Neurosci 5:32.

Andersen SL, Rutstein M, Benzo JM, Hostetter JC, Teicher MH (1997) Sex differences in dopamine receptor overproduction and elimination. Neuroreport 8:1495-1498.

Andersen SL, Thompson AP, Krenzel E, Teicher MH (2002) Pubertal changes in gonadal hormones do not underlie adolescent dopamine receptor overproduction. Psychoneuroendocrinology 27: 683-691.

Arnauld E, Dufy B, Pestre M, Vincent JD (1981) Effects of estrogens on the responses of caudate neurons to microiontophoretically applied dopamine. Neurosci Lett 21:325-331.

Baufreton J, Atherton JF, Surmeier DJ, Bevan MD (2005) Enhancement of excitatory synaptic integration by GABAergic inhibition in the subthalamic nucleus. J Neurosci 25:8505-8517.

Beach FA (1950) The snark was a boojum. Am Psychol 5:115-124. Becker JB (1999) Gender differences in dopaminergic function in striatum and nucleus accumbens. Pharmacol Biochem Behav 64: 803-812.

Becker JB, Chartoff E (2018) Sex differences in neural mechanisms mediating reward and addiction. Neuropsychopharmacology 44: 166-183.

Beery AK, Zucker I (2011) Sex bias in neuroscience and biomedical research. Neurosci Biobehav Rev 35:565-572.

Belleau ML, Warren RA (2000) Postnatal development of electrophysiological properties of nucleus accumbens neurons. J Neurophysiol 84:2204-2216.

Bernard V, Normand E, Bloch B (1992) Phenotypical characterization of the rat striatal neurons expressing muscarinic receptor genes. J Neurosci 12:3591-3600.

Brenowitz EA, Zakon HH (2015) Emerging from the bottleneck: benefits of the comparative approach to modern neuroscience. Trends Neurosci 38:273-278.

Calhoun JC (1962) The ecology and sociology of the Norway rat. U.S. Department of Health, Education, and Welfare: PHS NO. 1008.

Calin-Jageman R (2018) The new statistics for neuroscience majors: thinking in effect sizes. J Undergrad Neurosci Educ 16:E21-E25.

Calipari ES, Juarez B, Morel C, Walker DM, Cahill ME, Ribeiro E, Roman-Ortiz C, Ramakrishnan C, Deisseroth K, Han MH, Nestler EJ (2017) Dopaminergic dynamics underlying sex-specific cocaine reward. Nat Commun 8:13877.

Cao J, Dorris DM, Meitzen J (2016) Neonatal masculinization blocks increased excitatory synaptic input in female rat nucleus accumbens core. Endocrinology 157:3181-3196.

Cao J, Dorris DM, Meitzen J (2018) Electrophysiological properties of medium spiny neurons in the nucleus accumbens core of prepubertal male and female Drd1a-tdTomato line 6 BAC transgenic mice. J Neurophysiol 120:1712-1727.

Carroll ME, Anker JJ (2010) Sex differences and ovarian hormones in animal models of drug dependence. Horm Behav 58:44-56.

Cepeda C, André VM, Yamazaki I, Wu N, Kleiman-Weiner M, Levine MS (2008) Differential electrophysiological properties of dopamine D1 and D2 receptor-containing striatal medium-sized spiny neurons. Eur J Neurosci 27:671-682.

Chan CS, Peterson JD, Gertler TS, Glajch KE, Quintana RE, Cui Q, Sebel LE, Plotkin JL, Shen W, Heiman M, Heintz N, Greengard P, Surmeier DJ (2012) Strain-specific regulation of striatal phenotype in Drd2-eGFP BAC transgenic mice. J Neurosci 32:9124-9132.

Chen X, Grisham W, Arnold AP (2009) X chromosome number causes sex differences in gene expression in adult mouse striatum. Eur J Neurosci 29:768-776.

Cohen J (1977) Statistical power analysis for the behavioral sciences. Hillsdale, NJ: Lawrence Erlbaum.

Day M, Wang Z, Ding J, An X, Ingham CA, Shering AF, Wokosin D, Ilijic E, Sun Z, Sampson AR, Mugnaini E, Deutch AY, Sesack SR, Arbuthnott GW, Surmeier DJ (2006) Selective elimination of glutamatergic synapses on striatopallidal neurons in Parkinson disease models. Nat Neurosci 9:251-259.

De Vries GJ, Rissman EF, Simerly RB, Yang LY, Scordalakes EM, Auger CJ, Swain A, Lovell-Badge R, Burgoyne PS, Arnold AP 
(2002) A model system for study of sex chromosome effects on sexually dimorphic neural and behavioral traits. J Neurosci 22: 9005-9014.

Di Paolo T (1994) Modulation of brain dopamine transmission by sex steroids. Rev Neurosci 5:27-41.

Dorris DM, Cao J, Willett JA, Hauser CA, Meitzen J (2015) Intrinsic excitability varies by sex in pre-pubertal striatal medium spiny neurons. J Neurophysiol 113:720-729.

Dorris DM, Hauser CA, Minnehan CE, Meitzen J (2014) An aerator for brain slice experiments in individual cell culture plate wells. J Neurosci Methods 238:1-10.

Eckel LA, Houpt TA, Geary N (2000) Spontaneous meal patterns in female rats with and without access to running wheels. Physiol Behav 70:397-405.

Ellenbroek B, Youn J (2016) Rodent models in neuroscience research: is it a rat race? Dis Model Mech 9:1079-1087.

Enoksson T, Bertran-Gonzalez J, Christie MJ (2012) Nucleus accumbens D2- and D1-receptor expressing medium spiny neurons are selectively activated by morphine withdrawal and acute morphine, respectively. Neuropharmacology 62:2463-2471.

Escande MV, Taravini IR, Zold CL, Belforte JE, Murer MG (2016) Loss of homeostasis in the direct pathway in a mouse model of asymptomatic Parkinson's disease. J Neurosci 36:5686-5698.

Farries MA, Meitzen J, Perkel DJ (2005) Electrophysiological properties of neurons in the basal ganglia of the domestic chick: conservation and divergence in the evolution of the avian basal ganglia. J Neurophysiol 94:454-467.

Farries MA, Perkel DJ (2000) Electrophysiological properties of avian basal ganglia neurons recorded in vitro. J Neurophysiology 84: 2502-2513.

Farries MA, Perkel DJ (2002) A telencephalic nucleus essential for song learning contains neurons with physiological characteristics of both striatum and globus pallidus. J Neurosci 22:3776-3787.

Fieblinger T, Graves SM, Sebel LE, Alcacer C, Plotkin JL, Gertler TS, Chan CS, Heiman M, Greengard P, Cenci MA, Surmeier DJ (2014) Cell type-specific plasticity of striatal projection neurons in parkinsonism and L-DOPA-induced dyskinesia. Nat Commun 5:5316.

Friend DM, Kravitz AV (2014) Working together: basal ganglia pathways in action selection. Trends Neurosci 37:301-303.

Gerfen CR, Engber TM, Mahan LC, Susel Z, Chase TN, Monsma FJ Jr, Sibley DR (1990) D1 and D2 dopamine receptor-regulated gene expression of striatonigral and striatopallidal neurons. Science 250:1429-1432.

Gerfen CR, Surmeier DJ (2011) Modulation of striatal projection systems by dopamine. Annu Rev Neurosci 34:441-466.

Gertler TS, Chan CS, Surmeier DJ (2008) Dichotomous anatomical properties of adult striatal medium spiny neurons. J Neurosci 28:10814-10824

Gokce O, Stanley GM, Treutlein B, Neff NF, Camp JG, Malenka RC, Rothwell PE, Fuccillo MV, Südhof TC, Quake SR (2016) Cellular taxonomy of the mouse striatum as revealed by single-cell RNAseq. Cell Reports 16:1126-1137.

Goodliffe JW, Song H, Rubakovic A, Chang W, Medalla M, Weaver CM, Luebke JI (2018) Differential changes to D1 and D2 medium spiny neurons in the 12-month-old Q175+/- mouse model of Huntington's disease. PLoS One 13:e0200626.

Graveland GA, DiFiglia M (1985) The frequency and distribution of medium-sized neurons with indented nuclei in the primate and rodent neostriatum. Brain Res 327:307-311.

Ho H, Both M, Siniard A, Sharma S, Notwell JH, Wallace M, Leone DP, Nguyen A, Zhao E, Lee H, Zwilling D, Thompson KR, Braithwaite SP, Huentelman M, Portmann T (2018) A guide to single-cell transcriptomics in adult rodent brain: the medium spiny neuron transcriptome revisited. Front Cell Neurosci 12:159.

Hosseini-Kamkar N, Morton JB (2014) Sex differences in self-regulation: an evolutionary perspective. Front Neurosci 8:233.

Keeler JF, Pretsell DO, Robbins TW (2014) Functional implications of dopamine D1 vs. D2 receptors: a "prepare and select" model of the striatal direct vs. indirect pathways. Neuroscience 282:156175.
Klinck MP, Mogil JS, Moreau M, Lascelles BDX, Flecknell PA, Poitte T, Troncy E (2017) Translational pain assessment: could natural animal models be the missing link? Pain 158:1633-1646.

Koob GF, Volkow ND (2010) Neurocircuitry of addiction. Neuropsychopharmacology 35:217-238.

Kopec AM, Smith CJ, Ayre NR, Sweat SC, Bilbo SD (2018) Microglial dopamine receptor elimination defines sex-specific nucleus accumbens development and social behavior in adolescent rats. Nat Commun 9:3769.

Kramer PF, Christensen CH, Hazelwood LA, Dobi A, Bock R, Sibley DR, Mateo Y, Alvarez VA (2011) Dopamine D2 receptor overexpression alters behavior and physiology in Drd2-EGFP mice. $J$ Neurosci 31:126-132.

Kravitz AV, Tye LD, Kreitzer AC (2012) Distinct roles for direct and indirect pathway striatal neurons in reinforcement. Nat Neurosci 15:816-818.

Krebs HA (1975) The August Krogh principle: "For many problems there is an animal on which it can be most conveniently studied". J Exp Zool 194:221-226.

Kreitzer AC, Berke JD (2011) Investigating striatal function through cell-type-specific manipulations. Neuroscience 198:19-26.

Kreitzer AC, Malenka RC (2007) Endocannabinoid-mediated rescue of striatal LTD and motor deficits in Parkinson's disease models. Nature 445:643-647.

Kreitzer AC, Malenka RC (2008) Striatal plasticity and basal ganglia circuit function. Neuron 60:543-554.

Kress GJ, Yamawaki N, Wokosin DL, Wickersham IR, Shepherd GM, Surmeier DJ (2013) Convergent cortical innervation of striatal projection neurons. Nat Neurosci 16:665-667.

Lei W, Jiao Y, Del Mar N, Reiner A (2004) Evidence for differential cortical input to direct pathway versus indirect pathway striatal projection neurons in rats. J Neurosci 24:8289-8299.

Lieberman OJ, McGuirt AF, Mosharov EV, Pigulevskiy I, Hobson BD, Choi S, Frier MD, Santini E, Borgkvist A, Sulzer D (2018) Dopamine triggers the maturation of striatal spiny projection neuron excitability during a critical period. Neuron 99:540-554.e544.

Ma YY, Cepeda C, Chatta P, Franklin L, Evans CJ, Levine MS (2012) Regional and cell-type-specific effects of DAMGO on striatal D1 and D2 dopamine receptor-expressing medium-sized spiny neurons. ASN Neuro 4:e00077.

Ma YY, Henley SM, Toll J, Jentsch JD, Evans CJ, Levine MS, Cepeda C (2013) Drug-primed reinstatement of cocaine seeking in mice: increased excitability of medium-sized spiny neurons in the nucleus accumbens. ASN Neuro 5:257-271.

Maia TV, Frank MJ (2011) From reinforcement learning models to psychiatric and neurological disorders. Nat Neurosci 14:154-162.

Mani SK, Reyna AM, Alejandro MA, Crowley J, Markaverich BM (2005) Disruption of male sexual behavior in rats by tetrahydrofurandiols (THF-diols). Steroids 70:750-754.

Markaverich B, Mani S, Alejandro MA, Mitchell A, Markaverich D, Brown T, Velez-Trippe C, Murchison C, O'Malley B, Faith R (2002) A novel endocrine-disrupting agent in corn with mitogenic activity in human breast and prostatic cancer cells. Environ Health Perspect 110:169-177.

Maurice N, Liberge M, Jaouen F, Ztaou S, Hanini M, Camon J, Deisseroth K, Amalric M, Kerkerian-Le Goff L, Beurrier C (2015) Striatal Cholinergic Interneurons Control Motor Behavior and Basal Ganglia Function in Experimental Parkinsonism. Cell Rep 13:657-666.

McLean CP, Anderson ER (2009) Brave men and timid women? A review of the gender differences in fear and anxiety. Clin Psychol Rev 29:496-505

Meitzen J, Meisel RL, Mermelstein PG (2018) Sex differences and the effects of estradiol on striatal function. Curr Opin Behav Sci 23: 42-48.

Meitzen J, Pflepsen KR, Stern CM, Meisel RL, Mermelstein PG (2011) Measurements of neuron soma size and density in rat dorsal striatum, nucleus accumbens core and nucleus accumbens shell: differences between striatal region and brain hemisphere, but not sex. Neurosci Lett 487:177-181. 
Meitzen J, Weaver AL, Brenowitz EA, Perkel DJ (2009) Plastic and stable electrophysiological properties of adult avian forebrain song-control neurons across changing breeding conditions. J Neurosci 29:6558-6567.

Mermelstein PG, Becker JB, Surmeier DJ (1996) Estradiol reduces calcium currents in rat neostriatal neurons via a membrane receptor. J Neurosci 16:595-604.

Mu P, Moyer JT, Ishikawa M, Zhang Y, Panksepp J, Sorg BA, Schlüter OM, Dong Y (2010) Exposure to cocaine dynamically regulates the intrinsic membrane excitability of nucleus accumbens neurons. J Neurosci 30:3689-3699.

O’Donnell P, Grace AA (1993) Physiological and morphological properties of accumbens core and shell neurons recorded in vitro. Synapse 13:135-160.

Onn SP, Berger TW, Grace AA (1994a) Identification and characterization of striatal cell subtypes using in vivo intracellular recording in rats: I. Basic physiology and response to corticostriatal fiber stimulation. Synapse 16:161-180.

Onn SP, Berger TW, Grace AA (1994b) Identification and characterization of striatal cell subtypes using in vivo intracellular recording in rats: II. Membrane factors underlying paired-pulse response profiles. Synapse 16:195-210.

Onn SP, Berger TW, Grace AA (1994c) Identification and characterization of striatal cell subtypes using in vivo intracellular recording and dye-labeling in rats: III. Morphological correlates and compartmental localization. Synapse 16:231-254.

Planert H, Berger TK, Silberberg G (2013) Membrane properties of striatal direct and indirect pathway neurons in mouse and rat slices and their modulation by dopamine. PLoS One 8:e57054.

Proaño S, Morris HJ, Kunz LM, Dorris DM, Meitzen J (2018) Estrous cycle-induced sex differences in medium spiny neuron excitatory synaptic transmission and intrinsic excitability in adult rat nucleus accumbens core. J Neurophysiol 120:1356-1373.

Reig R, Silberberg G (2014) Multisensory integration in the mouse striatum. Neuron 83:1200-1212.

Remage-Healey L, Krentzel AA, Macedo-Lima M, Vahaba D (2017) Species diversity matters in biological research. Policy Insights Behav Brain Sci 4:210-218.

Schier CJ, Marks WD, Paris JJ, Barbour AJ, McLane VD, Maragos WF, McQuiston AR, Knapp PE, Hauser KF (2017) Selective vulnerability of striatal D2 versus D1 dopamine receptor-expressing medium spiny neurons in HIV-1 tat transgenic male mice. J Neurosci 37:5758-5769.

Sebel LE, Graves SM, Chan CS, Surmeier DJ (2017) Haloperidol selectively remodels striatal indirect pathway circuits. Neuropsychopharmacology 42:963-973.

Shansky RM, Woolley CS (2016) Considering sex as a biological variable will be valuable for neuroscience research. J Neurosci 36:11817-11822.

Shuen JA, Chen M, Gloss B, Calakos N (2008) Drd1a-tdTomato BAC transgenic mice for simultaneous visualization of medium spiny neurons in the direct and indirect pathways of the basal ganglia. $J$ Neurosci 28:2681-2685.

Tallaksen-Greene SJ, Albin RL (1996) Splice variants of glutamate receptor subunits 2 and 3 in striatal projection neurons. Neuroscience 75:1057-1064.

Tansey EM, Arbuthnott GW, Fink G, Whale D (1983) Oestradiol-17 beta increases the firing rate of antidromically identified neurones of the rat neostriatum. Neuroendocrinology 37:106-110.

Tepper JM, Sharpe NA, Koós TZ, Trent F (1998) Postnatal development of the rat neostriatum: electrophysiological, light- and electron-microscopic studies. Dev Neurosci 20:125-145.
Thibault D, Loustalot F, Fortin GM, Bourque MJ, Trudeau LE (2013) Evaluation of D1 and D2 dopamine receptor segregation in the developing striatum using BAC transgenic mice. PLoS One 8:e67219.

Ting JT, Feng G (2014) Recombineering strategies for developing next generation BAC transgenic tools for optogenetics and beyond. Front Behav Neurosci 8:111.

Tozzi A, de lure A, Tantucci M, Durante V, Quiroga-Varela A, Giampa C, Di Mauro M, Mazzocchetti P, Costa C, Di Filippo M, Grassi S, Pettorossi VE, Calabresi $\mathrm{P}$ (2015) Endogenous $17 \beta$-estradiol is required for activity-dependent long-term potentiation in the striatum: interaction with the dopaminergic system. Front Cell Neurosci 9:192.

Uryu K, Butler AK, Chesselet MF (1999) Synaptogenesis and ultrastructural localization of the polysialylated neural cell adhesion molecule in the developing striatum. J Comp Neur 405:216-232.

Valjent E, Bertran-Gonzalez J, Hervé D, Fisone G, Girault JA (2009) Looking BAC at striatal signaling: cell-specific analysis in new transgenic mice. Trends Neurosci 32:538-547.

Venance L, Glowinski J (2003) Heterogeneity of spike frequency adaptation among medium spiny neurones from the rat striatum. Neuroscience 122:77-92.

Villalon Landeros R, Morisseau C, Yoo HJ, Fu SH, Hammock BD, Trainor BC (2012) Corncob bedding alters the effects of estrogens on aggressive behavior and reduces estrogen receptor- $\alpha$ expression in the brain. Endocrinology 153:949-953.

Vorobjev VS, Sharonova IN, Haas HL, Sergeeva OA (2000) Differential modulation of AMPA receptors by cyclothiazide in two types of striatal neurons. Eur J Neurosci 12:2871-2880.

Will TR, Proaño SB, Thomas AM, Kunz LM, Thompson KC, Ginnari LA, Jones CH, Lucas SC, Reavis EM, Dorris DM, Meitzen J (2017) Problems and progress regarding sex bias and omission in neuroscience research. eNeuro 4:ENEURO.0278-0217.2017.

Willett JA, Johnson AG, Vogel AR, Patisaul HB, McGraw LA, Meitzen $J(2018)$ Nucleus accumbens core medium spiny neuron electrophysiological properties and partner preference behavior in the adult male prairie vole, Microtus ochrogaster. J Neurophysiol 119: 1576-1588.

Willett JA, Will TR, Hauser CA, Dorris DM, Cao J, Meitzen J (2016) No evidence for sex differences in the electrophysiological properties and excitatory synaptic input onto nucleus accumbens shell medium spiny neurons. eNeuro 3:ENEURO.0147-0115.2016.

Wissman AM, McCollum AF, Huang GZ, Nikrodhanond AA, Woolley CS (2011) Sex differences and effects of cocaine on excitatory synapses in the nucleus accumbens. Neuropharmacology 61:217227.

Wong JE, Cao J, Dorris DM, Meitzen J (2016) Genetic sex and the volumes of the caudate-putamen, nucleus accumbens core and shell: original data and a review. Brain Struct Funct 221:42574267.

Yoest KE, Quigley JA, Becker JB (2018) Rapid effects of ovarian hormones in dorsal striatum and nucleus accumbens. Horm Behav 104:119-129.

Young E, Korszun A (2010) Sex, trauma, stress hormones and depression. Mol Psychiatry 15:23-28.

Young JW, Jentsch JD, Bussey TJ, Wallace TL, Hutcheson DM (2013) Consideration of species differences in developing novel molecules as cognition enhancers. Neurosci Biobehav Rev 37: 2181-2193.

Zurkovsky L, Brown SL, Boyd SE, Fell JA, Korol DL (2007) Estrogen modulates learning in female rats by acting directly at distinct memory systems. Neuroscience 144:26-37. 